\title{
Millennials' Expectations of Life at the University and the Workplace: A Malaysian Perspective
}

\author{
Humaira Raslie ${ }^{1}$, Salina Pit $^{2} \&$ Su-Hie Ting ${ }^{3, *}$ \\ ${ }^{1}$ Centre for Language Studies, Universiti Malaysia Sarawak, 94300 Kota Samarahan, \\ Sarawak, Malaysia \\ *Corresponding author: Universiti Malaysia Sarawak, 94300 Kota Samarahan, Sarawak, \\ Malaysia. E-mail: shting@cls.unimas.my
}

Received: December 31, 2015 Accepted: January 24, 2016 Published: September 1, 2016

doi:10.5296/ije.v8i3.9982ＵRL: http://dx.doi.org/10.5296/ije.v8i3.9982

\begin{abstract}
This study examined the millennial's expectations of life at the university and the workplace. Questionnaire data were obtained from 142 students aged 20 to 24 in a Malaysian public university from different disciplines. The results showed that most of the participants were highly feedback oriented and expected instant face-to-face feedback from their lecturers, particularly when in emails. They relied on lecture notes to understand the lectures, but would also look for supplementary reading materials. They expected lecturers to deliver interesting lectures but would attend boring lectures to comply with lecture attendance rules. The results also suggest that many participants would not sacrifice their personal time to meet either assignment or work deadlines because they expected deadline extensions. Although the participants preferred positive comments, they also expected to be reprimanded for unsatisfactory work performance. They also expected a fair amount of individual work compared to group work at the workplace. The findings suggest that the participants generally had realistic expectations of university and work life.
\end{abstract}

Keywords: millennial, feedback, work-life balance, work expectations 


\section{Introduction}

The rise of the $\mathrm{Y}$ generation or the Millennials is one of the distinctive markers of the $21^{\text {st }}$ century. Black (2010) characterised Millennials as "those who were born between the years 1981 to 2001" (p. 92) while Woods, Wilson, and Walkovich (2011) set the years of birth between 1981 and 1999. On the other hand, according to Meister and Willyerd (2010), the Millennials were born between the years 1977 to 1997. Although there are differing opinions on the range of years marking the age of the Millennials, these authors share a common view that there is a generational distinctiveness (Lindquist, 2008) shared by individuals who were born between the period of early 1980 s to late 1990 s.

Numerous researchers have attempted to characterise Millennials. For a start, the Millennials are described as the "Look at Me" generation due to their consistent need for attention (Pew Research Centre, 2007, as cited in Myers \& Sadaghiani, 2010); built-in "I-am-special" self-image (Lindquist, 2008); and excessive display of confidence and narcissism (Black, 2010; Myers \& Sadaghiani, 2010).

The distinctive characteristics of Millennials have been attributed to their family upbringing. Growing up in a nurturing environment with helicopter parents (Black, 2010; Rainer \& Rainer, 2011) who constantly remind them of how special they are (Linquist 2008; Myers \& Sadaghiani, 2010), Millennials consider family and friends very vital. They are also more socially-conscious (Meister \& Willyerd, 2010) than the generations before them. Their social inclination is further enhanced by their active engagement with the social media and group-based online activities such as role-playing online games. These interactions condition them to be very receptive towards diversity of any form as well as working in teams. Moreover, they are also privy to a huge amount of information all the time; a circumstance hemmed by their adeptness and dependency on the world wide web. As a result, they develop a substantial level of social conscience, so much so that volunteerism becomes a permanent lifestyle for some of them.

The distinctive characteristics of the Millennials influence the way they learn. As a result, the $21^{\text {st }}$ century also witnesses inter-generational clash between the veterans (school principal, university rector, faculty dean, registrar), talents (professors, associate professors, senior lecturers) and Millennials (students) (Lindquist, 2008). Frustrated academics have employed seasoned pedagogical methods only to find that they do not work with the Millennials (Ting, 2013). This complex circumstance creates an andragogic importance to address the uniqueness of the Millennials vis-à-vis pedagogical practices. An example of a study on the characteristics of the Millennial students is that of Black (2010) who examined "how they use information and learn" (p. 92). Through interviewing key administrative personnel, reading and observation, Black (2010) found that the Millennials are: 1) assertive and confident, 2) prefer group and team work, 3) highly tolerant towards various forms of diversity, 4) have friends beyond their geographic reach, 5) collaborative, 6) dependent upon technology (digital native), 7) demanding, impatient and have short attention spans, 8) spiritual, and 9) share values of parents and society. In the same vein, much of these characteristics also spew from technological advancements and the participants' family background. Other researchers 
who have embarked on this mission include Woods et al. who investigated how instructional strategies match the Millennials' characteristics and Reilly (2012) who reached similar conclusions on using technology to hasten feedback as well as employing online videos and power point presentation to engage participation, tap into their cultural reality and lengthen attention span. These traits are similar to the ones identified in the professional domain, as will be described next.

At the present time, Millennials are in their twenties and thirties, and have entered the workforce. At approximately 76 million (Black, 2010; Woods et al., 2011) and consisting of students who are about to graduate, graduates as well as young employees, the Millennials currently form the biggest percentage of human capital in the world (Meister \& Willyerd, 2010). Most industries would have Baby Boomers or veterans, Generation X or talents as well as the Millennials working together under one roof but playing different roles (Lindquist, 2008). According to Lindquist, the veterans would be doing consultancy, the talents would most likely be in the position of a senior executive or workforce manager while the Millennials will be the junior staff or the subordinates. Complications are expected to arise due to the generational clash between the three generational cohorts in terms of work culture, priorities and wavelength. For instance, the superiors might find the Millennials too self-absorbed and undependable while the Millennials, on the hand, might perceive their bosses as rigid and obstructive to their personal life.

In the professional domain, research has shown that there are generational clashes between the Millennials, Generation X and the Baby Boomers. Researchers have found Millennials to be impatient; pertinently in terms of receiving feedback and achieving success. For example, Meister and Willyerd conducted a study on the Millennials' values, behaviour at work and expectation of employers involving 20,000 professionals working in various industries. Their findings show that Millennials expect round-the-clock mentoring from their incumbents. In fact, guidance from superiors, from their perspective is an "entitlement"- not a "privilege". Lindquist did a similar study but on three different generations of accountants and found a matching result: Millennial accountants are more concerned with the privileges obtainable from their employer as opposed to their own contribution. The sense of "earning your keep"; prevalent in the previous generations is not observable in this new breed of accountants. On the contrary, Meister and Willyerd divulged that although Millennials have high expectations of their employer, they also place themselves on a pedestal; setting very high standard of personal and career goal to achieve.

Other researchers have found more evidence of the generational clash between the Millennials, Generation X and the Baby Boomers in terms of work culture, priorities and wavelength (Lindquist, 2008; Meister \& Willyerd, 2010). Firstly, the Millennials prize self-fulfillment over job security. Hence, they lack organizational loyalty and do not mind job-hopping or continuing their studies after graduation if the employment climate is unfavourable to their career aspiration. Further studies enable them to earn more and have better career paths, and ultimately this gives Millennials "the time and means to travel and visit [their] family" (Rainer \& Rainer, 2011, p. 108). Secondly, their professional goal is to achieve work-life balance, not wealth. Therefore, workplace flexibility is a crucial factor to 
the Millennials. Unlike the Baby Boomer Generation and the Generation X, the current generation is not keen on sacrificing their personal life and time for their job. They will also not hesitate giving up their career or any form of career advancement if they feel that their personal life, family and friends are threatened by their current job. In terms of work culture, the Millennials prefer teamwork and diversity. They enjoy obtaining new skills and exercising their creativity while making new friends at work. Finally, as socially-conscious individuals with a social conscience, "the sense of purpose is a key factor in their job satisfaction" (Meister \& Willyerd, 2010, p. 1). Hence, the Millennials always try to connect to a larger purpose, even in the professional domain.

Much is known about the characteristics of Millennials in the academic and professional settings but the studies have been largely conducted in Western settings. Because of the technological advancements which heighten connectivity among Millennials beyond their geographic confines, it is possible that Millennials are similar in various parts of the world. However, this assumption needs to be verified by empirical evidence. At this current juncture, relatively little is known about the characteristics of Millennials in Asian settings. Reilly (2012) stresses on this point by mentioning that "while Gen Y receives substantial attention in the professional literatures of many fields, this is not true in ELT [English language teaching] journals" (p. 2). In addition, in the professional domain, stakeholders of various industries have been progressively conducting research on their Millennial employees; predominantly in areas which could match and assimilate the institution's work culture to their characteristics, aspirations and needs (Lindquist, 2008; Meister \& Willyerd, 2010; Myers \& Sadaghiani, 2010; Woods et al., 2011). In Malaysia, an example of such a company is Shell, a multinational oil and gas company. It is a strategic move to research Millennials in the workplace context because the generational clash between the Millennials, Generation X and the Baby Boomers, if not addressed, would lead to either the lack of manpower or underperformance in many companies and professional institutions. "Today's businesses need to at least understand the young generation - what challenges them what inspires them what motivates them - to engage successfully with the Millennials" to reduce turnover (Twenge \& Campbell, 2012, p. 11). This study examined the Millennial's expectations of life at the university and the workplace.

\section{Method}

The participants of this study were 142 undergraduate students at a Malaysian non-research intensive university. They were from both arts and science disciplines. Their age range was from 20 to 24, placing them firmly within the age range of Millennials. The participants were from various ethnic and language backgrounds (e.g., Chinese, Malay, Iban, Bidayuh, Kadazandusun and other indigenous). Most had completed Form Six, a level equivalent to "A" level before entering university although some others had matriculation studies. These participants have not held full-time employment.

These participants were enrolled in English proficiency subjects taught by the three researchers. Towards the end of the 14-week semester, the researchers informed their 
students of their interest in studying the behaviour of Millennials, and sought their participation in the study. They were told that they could choose not to participate in the study. Questionnaires were distributed in class and collected after 15 minutes. Those who did not wish to participate in the study did not return the questionnaire. As no identifying information (e.g., name or identification number) were required in the questionnaire, the participants could remain anonymous. This is to ensure that there is no bias in conducting the study as the researchers could not identify either those returned the questionnaire or those who refrained from participating in the study. The data were collected in 2015.

The questionnaire comprised 24 items on the expectations of life at the university and the workplace, based on characteristics of Millennials identified by various researchers, particularly Ng, Schweitzer, and Lyons (2010). Various aspects of life at the university were examined using six pairs of questions - these would be based on the participants' experiences. One set of questions was worded with their expectations of their lecturers as the subject (e.g., I expect my lecturers to provide me the reading materials for the course) while the other set of questions highlighted the Millennials as the subject (e.g., I usually look for extra reading materials for the course) but the subject matter was the same. Various aspects of working life were examined in the same manner using six pairs of questions. An example of a pair of questions is as follows:

1. I expect my employer to give me more time if I cannot finish a project on time.

2. I expect to work at night and weekends to finish off projects to meet the deadline.

As most of the participants have not held full-time employment, this set of items examined their expectations of their working life.

The participants were asked to indicate their level of agreement to the statements using a five point Likert scale. The middle option was labelled as "have not thought about it" instead of the usual "neither agree or disagree" to allow space for participants who have not formed an opinion about the issue to indicate their response.

The internal consistency reliability (Cronbach Alpha coefficient) for the questionnaire was 0.821 . The questionnaire had been employed in another study on polytechnic students, and the findings were presented in a conference (Ooi \& Ting, 2015a, 2015b). The audience comprising lecturers and researchers in related fields had deemed the questionnaire feasible for such studies and did not point out methodological shortfalls of the study. The results suggest that the questionnaire on the millennial's experiences at university and expectations of the workplace was valid and reliable when used in the Malaysian setting.

\section{Results and Discussion}

This section presents the results on the Millennial's expectations of their life in the university and in the workplace. 


\subsection{Millennial's Expectations of Their Life in the University}

Table 1 shows the mean scores on participants' expectations of six aspects of their university life. The results in Table 1 show that the mean scores were above the mid-point of 3 on a Likert-scale of 1 to 5, indicating that the participants generally agreed with the items with the exception of Item B8 ("I usually expect my lecturers to be too busy to see me immediately") which had a mean score of 3.30, close to the mid-point of the five-point Likert-scale. This result indicates that one-third of the participants reported that they had not thought about it (5 strongly disagreed, 25 disagreed, 50 have not thought about it, 46 agreed, 16 strongly agreed). There were more who agreed (43.66\%) than those who disagreed $(21.13 \%)$, suggesting that the participants fell into two groups: those who had not thought about it because they did not see their lecturers and those who are aware that their lecturers could not give them time whenever the participants needed to see them. However, most of the participants agreed with the other item in this pair (Mean of 3.94 for Item B5, "I expect my lecturers to give me feedback or respond to my email within 24 hours"). This shows that the participants expected instant feedback to their email. There is an apparent contradiction in the results because both items examined the instantaneity of the lecturer feedback. The contradiction can be resolved by looking at the mode of feedback - it seems that the participants did not expect lecturers to be always around for face-to-face consultation sessions but they expected a quick email response. So far the studies on Millennials which highlight the Millennials' expectation for frequent feedback have not examined how their expectation might vary with mode of feedback. For example, Wilson and Gerber (2008) have likened the Millennials' expectation for frequent feedback to how ATM receipts provide immediate feedback on account balance. Meister and Willyerd also found that Millennials expect to get feedback round the clock.

Next, the participants generally agreed that they relied on their lecturers for reading materials but they also agreed that they would look for the materials themselves. Table 1 shows a slightly higher mean for Item B1 (3.96 for "I expect my lecturers to provide me the reading materials for the course") than Item B12 (3.68 for "I usually look for extra reading materials for the course"). The stronger agreement with the former indicate that while more expected their lecturers to supply them with the reading materials, and fewer would look for extra reading materials themselves.

Taken together the results on the participants' response to assignment deadlines indicate that they hoped their lecturers would extend deadlines (mean of 3.63 for Item B2) and would burn the midnight oil to meet deadlines (mean of 3.80 for Item B11). The means are below four, indicating that many would not sacrifice their sleep to meet assignment deadlines because life is more than studies. This results concur with Meister and Willyerd who found that the Millennials are not keen to sacrifice their personal life and time for their job.

The participants' attitude of valuing their personal time seemed to carry into their response to their performance in the course. Many of the participants expected their lecturers to give them another chance to redo a badly done assignment (mean of 4.26), and they felt that they would work harder to improve their scores (mean of 4.37). From our experience of teaching the university students, we found that a handful of students would ask for a second chance to 
submit their assignment after they found out that their marks were low and if they were in danger of failing the course. This request was usually not granted as a normative practice in our university in order to ensure fairness to other students who submitted their assignments on time.

Table 1. Mean Scores on Participants' Expectations of Various Aspects of Their University Life

\begin{tabular}{|c|c|c|c|}
\hline Item & Mean & Item & Mean \\
\hline $\begin{array}{l}\text { B1. I expect my lecturers to provide me } \\
\text { the reading materials for the course. }\end{array}$ & 3.96 & $\begin{array}{l}\text { B12. I usually look for extra } \\
\text { reading materials for the course. }\end{array}$ & 3.68 \\
\hline $\begin{array}{l}\text { B2. I expect my lecturers to give me } \\
\text { more time if I cannot finish an } \\
\text { assignment on time. }\end{array}$ & 3.63 & $\begin{array}{l}\text { B11. I usually do my assignments } \\
\text { late at night and weekends to } \\
\text { meet the deadline. }\end{array}$ & 3.80 \\
\hline $\begin{array}{l}\text { B3. I expect my lecturers to help me to } \\
\text { understand the lectures. }\end{array}$ & 4.24 & $\begin{array}{l}\text { B10. I usually try to understand } \\
\text { difficult parts of lectures on my } \\
\text { own (e.g., ask my friends). }\end{array}$ & 4.13 \\
\hline $\begin{array}{l}\text { B4. I expect my lecturers to give me } \\
\text { another chance to do the assignment if I } \\
\text { do badly. }\end{array}$ & 4.26 & $\begin{array}{l}\text { B9. When I get low marks in } \\
\text { assignments, I usually work } \\
\text { harder to improve my scores. }\end{array}$ & 4.37 \\
\hline $\begin{array}{l}\text { B5. I expect my lecturers to give me } \\
\text { feedback or respond to my email within } \\
24 \text { hours. }\end{array}$ & 3.94 & $\begin{array}{l}\text { B8. I usually expect my lecturers } \\
\text { to be too busy to see me } \\
\text { immediately. }\end{array}$ & 3.30 \\
\hline $\begin{array}{l}\text { B6. I expect my lecturers to make } \\
\text { lectures interesting for me. }\end{array}$ & 4.27 & $\begin{array}{l}\text { B7. I usually attend all lectures, } \\
\text { even when they are boring. }\end{array}$ & 3.91 \\
\hline
\end{tabular}

1 for "strongly disagree", 2 for "disagree", 3 for "have not thought about it", 4 for "agree", and 5 for "strongly agree"

The results from another pair of items showed the participants' belief that the lecturer and the students share the responsibility for their learning. Table 1 shows that the participants expected their lecturers to help them understand the lectures (mean of 4.24 for Item B3), but on their part they would try to understand difficult parts of lectures on their own (mean of 4.13 for Items B10). The results indicate that the participants knew that it was their responsibility to understand the lectures and a large proportion were prepared to put in many hours of extra readings although it would infringe on their personal time.

Because of the attendance requirement at many Malaysian universities ( $80 \%$ of total number of lectures in a semester), an item was formulated to find out whether the participants would attend all the lectures regardless of whether they were interesting or boring. Table 1 shows that the participants expected their lecturers to make the lectures interesting for them as an incentive to attend the lectures (mean of 4.27) but they would sit through boring lectures 
(mean of 3.91). They felt the compulsion to sit through all the lectures during the 14-week semester, so as not to miss more than $20 \%$ of the total number of lectures during the semester to ensure that they would not be barred from the final semester examination. The participants in this study worked within the rules but did not rewrite the rules - a characteristic of Millennials as opposed to Generation X who reject rules (Thielfoldt \& Scheef, 2004). Rule compliance aside, considering that the participants rely on lecture notes to understand lectures, it is important for them not to miss lectures or else the Powerpoint slides may not make much sense.

At this point of the discussion, the millennials in this study seem to be confirming the "self-centered" and "unmotivated" attributes which they are perceived to possess (Myers \& Sadaghiani, 2010). However, the PricewaterhouseCoopers' (2009) nationwide survey on Malaysian millennials at work revealed that Malaysian millennials prefer training benefits over medical and housing benefits from their employers because of the direct impacts these said benefits have on their career development. PricewaterhouseCoopers' finding explains the Malaysian millennials' willingness to attend lectures which they deem uninteresting to avoid being barred from the final examination. Although flexibility is important, their self-reliant attitude (Asian Institute of Finance, 2015; PricewaterhouseCoopers, 2009) reminds them that the state of their future is in their hands - and a large part of their future is their career. As such, they will engage in activities to ensure that their future is somewhat stable; and this includes attending boring lectures.

In short, the participants were highly feedback oriented and expected instantaneous email feedback although they were aware that their lecturers might be too busy to see them immediately. They attended enough lectures to fulfil the attendance requirements and viewed their learning as a joint responsibility of lecturer and students. The results also suggest that many participants would not sacrifice their personal time to meet assignment deadlines, fitting the characterization of Millennials as those who value their personal time. In other words, they may be willing to compromise on quality (getting poorer grades) to maintain their study-personal life balance.

\subsection{Millennial's Expectations of Their Life in the Workplace}

Compared to expectations of university life, the aspects on feedback and meeting deadlines are also explored in the questionnaire items on expectations of life in the workplace but the new aspects covered are group work, leadership and negative evaluations. Table 2 presents the mean scores on participants' expectations of six aspects of their working life. The emphasis was on their new job because the participants had not held a full-time job before their university studies. 
Table 2. Mean Scores on Participants' Expectations of Various Aspects of Their Working Life

\begin{tabular}{|c|c|c|c|}
\hline Item & Mean & Item & Mean \\
\hline $\begin{array}{l}\text { C13. I expect my employer to guide } \\
\text { me to do my new job. }\end{array}$ & 4.07 & $\begin{array}{l}\text { C24. I expect to use most of what I } \\
\text { have learnt at university to do my new } \\
\text { job. }\end{array}$ & 4.08 \\
\hline $\begin{array}{l}\text { C14. I expect my employer to give } \\
\text { me more time if I cannot finish a } \\
\text { project on time. }\end{array}$ & 3.60 & $\begin{array}{l}\text { C23. I expect to work at night and } \\
\text { weekends to finish off projects to } \\
\text { meet the deadline. }\end{array}$ & 3.54 \\
\hline $\begin{array}{l}\text { C15. I expect to lead my colleagues } \\
\text { in my work. }\end{array}$ & 3.89 & $\begin{array}{l}\text { C22. I expect to follow instructions of } \\
\text { my colleague to do my work. }\end{array}$ & 3.65 \\
\hline $\begin{array}{l}\text { C16. I expect to work in groups in } \\
\text { my new job. }\end{array}$ & 3.99 & $\begin{array}{l}\mathrm{C} 21 . \mathrm{I} \text { expect to do jobs on my own in } \\
\text { my new job. }\end{array}$ & 3.58 \\
\hline $\begin{array}{l}\text { C17. I expect my employer to give } \\
\text { me feedback on my work in } \\
\text { progress. }\end{array}$ & 4.32 & $\begin{array}{l}\text { C20. I expect to finish my work } \\
\text { before showing it to my employer for } \\
\text { feedback. }\end{array}$ & 4.20 \\
\hline $\begin{array}{l}\text { C18. I expect my employer to give } \\
\text { positive comments on my work. }\end{array}$ & 4.08 & $\begin{array}{l}\text { C19. I expect to be scolded sometimes } \\
\text { for bad work in my new job. }\end{array}$ & 3.75 \\
\hline
\end{tabular}

1 for "strongly disagree", 2 for "disagree", 3 for "have not thought about it", 4 for "agree", and 5 for "strongly agree"

The questionnaire used in this study had a disproportionate number of questions related to feedback because this is a characteristic of Millennials that has attracted a great deal of attention. There were two pairs of items dealing with feedback (C13 and C24, and $\mathrm{C} 17$ and C20). The means were above 4 showing that the participants agreed with the statements. Items C13 and C24 were formulated to find out whether the participants were dependent on their employer for guidance or self-reliant in carrying out their work. While they expected their employer to guide them in their new job (mean of 4.07), they felt that what they had learnt at university could help them to carry out their new job responsibilities (mean of 4.08). This would suggest that they were resourceful to learn how to manage a new job.

Knowing that they expected close guidance from lecturers while they were at university, the next pair of items delved further into the nature of feedback they expected from their employers. The results showed that the participants expected their employers to give them continuous feedback on work in progress (mean of 4.32) and upon completion of their work (mean of 4.20). Their expectations on close guidance in their new job are similar to the Millennials in Meister and Willyerd's study who expect round-the-clock mentoring from their incumbents. Rainer and Rainer (2011) stated that "most Millennials will not function well vocationally if they aren't getting regular feedback" (p. 140).

Related to feedback is the nature of feedback. Much as they prefer positive comments on their work (Item C18, mean of 4.08), the participants also expected some reprimands (Item 
C19, mean of 3.75). The participants in this study were realistic in their expectations of receiving negative evaluations although Millennials have been depicted as being nurtured and given acclaim for their every achievement by their parents (Stein, 2013).

The mean scores for Items C14 and C23 are similar to the results on the participants' response on meeting deadlines in the university setting. As the mean scores were close to three, this indicate that the participants were divided in their views on whether their employers would extend project deadlines (3.60 for Item C14) or they would work extra hours to complete their projects on time (3.54 for Item C23). This is an aspect which they were not sure about as they had not encountered such work situations. The results were analysed further to find out whether more agreed or disagreed with these items. For Item C14 on whether their expectations on project deadline extension, there were 33 (or 23.24\%) participants who had not thought about this matter. More participants expected their employers to grant them an extension ( 84 or $59.15 \%$ ) and only 20 (or $14.08 \%$ ) participants felt that their employer would hold them to the deadlines. As for Item C23 on whether they would work after hours at night and on weekends to finish a project, 29 (or 20.42\%) participants had not thought about this matter. More felt that they would sacrifice personal time to complete their work ( 85 or $59.86 \%$ ) and only 28 (or $19.72 \%$ ) would not put their work as priority. Based on the similar percentage of responses, the participants who expected deadline extensions $(59.15 \%)$ is also the group who said that they would work after office hours to meet deadlines $(59.86 \%)$. Therefore, it can be surmised that although some were willing to work extra hours, they might not allow their work to encroach too much into their personal time because they still expected to be given more time if they could not finish projects on time. These results concur with findings of other studies on the Millennials' prioritizing work-life balance (Lindquist, 2008; Meister \& Willyerd, 2010).

Next, teamwork skill is one of the seven soft skills emphasized by the Malaysian government for university students ("Modul Pembangunan Kemahiran Insaniah untuk IPT Malaysia" [Module for development of soft skills for institutions of higher learning in Malaysia], n.d). To achieve teamwork in the professional setting, the employees should be able to lead and to be led. Besides that, they should be able to work independently to do their part so that the team can achieve the common outcome. Further analysis revealed that more than half of the participants ( 83 or $58.45 \%$ ) expected to function on their own in their new job (mean of 3.58 , Item C21). Even more participants (116 or $81.69 \%$ ) expected to work in groups in their new job (mean of 3.99, Item C16) (Table 2). However, the slightly higher mean score for C16 than C21 indicates that the participants expected more group work than individual work. Black (2010) found that the Millennials prefer group and team work. In the present study, we did not ask the participants about their preference but rather their expectations of the likelihood of doing group or individual work in their new job. Nevertheless, it can be assumed that Malaysian university students are used to functioning in groups because of the university emphasis on teamwork in many coursework assignments. Therefore, they are already conditioned to prefer group work - no different from Millennials elsewhere.

Finally, the participants' expectation of how leadership functions in the workplace was examined. Leadership is another soft skill emphasized in Malaysian tertiary education. 
Besides knowledge of basic leadership theories, university students are expected to develop ability to lead projects, understand and take the roles of both the team leader and team member as well as supervise team members. Table 2 shows mean scores close to four, indicating marginal agreement with the statements on expectations to lead their colleagues at work (mean of 3.89, Item C15) and to follow instructions of colleagues (mean of 3.65, Item C22). Further examination of the results showed that only a minority had not thought about the issue $(27.47 \%$ and $23.94 \%$ for $\mathrm{C} 13$ and $\mathrm{C} 22$ respectively) but most of the participants agreed with the two statements. The participants clearly knew that they were expected to be both leaders and followers in their work. From Ooi and Ting's (2014) analysis of job advertisements for fresh university graduates from various disciplines, they found that leadership was mentioned as a desired attribute in only $16.19 \%$ of the 105 advertisements analysed. In entry level positions, Malaysian employers expect their employees to work under a supervisor rather than lead a team. The slightly higher mean score for Item C15 compared to Item C22 shows that the participants in this study were aware of this fact.

To sum up, most of the participants in this study expected close mentoring and guidance from their employers, supporting the findings of Meister and Willyerd and other researchers who report that Millennials expect constant guidance and feedback. The participants also expected to be reprimanded for unsatisfactory work performance although they prefer to get positive comments on their work. This aspect does not seem to have been examined in other studies; hence, a comparison cannot be made. Other aspects of the participants' expectations of work life concur with existing research on the Millennials in terms of work-life balance and group work. They would make some sacrifice of personal time to meet work deadlines but since they expected deadline extensions, they might not give it their all to comply with work schedules. There is also the possibility that they might leave their team members to carry the responsibility of ensuring good work completion unless it is individual work, and they expected a fair amount of this compared to group work.

\section{Conclusion}

The study examined the Millennial's expectations of life at the university and the workplace from the perspective of Malaysian university students. The findings revealed a strong link between what the Millennials expect from their university and working life in work-life balance. Whether they are students or employees, the Millennials are generally not keen to sacrifice their personal time to meet either academic or work deadlines. This means that they might have to forego quality to meet deadlines. The Millennials in the present study also expect group work and constant feedback from their lecturers and would-be employers. The findings of the present study confirmed existing findings on how Millennials differ from Generation X and the Baby Boomers in terms of frequent feedback and priority on work-life balance (Lindquist, 2008; Meister \& Willyerd, 2010; Myers \& Sadaghiani, 2010; Woods et al., 2011). The study has added to the literature on characteristics of Millennials because few studies of this nature has been conducted in the Malaysian setting. In particular, the study has investigated less known aspects of Millennials, which include expectations of reprimands in 
the workplace for unsatisfactory work, rule compliance and how expectations of instant feedback may vary with mode of communication. The Millennials in the present study did not expect to meet their lecturers whenever they were needed but they expected instantaneous response to their email queries. The findings suggest that the mode of communication influences their expectation on immediacy of feedback. In fact, Koeller (2012) proposed certain frequencies in which emails, announcements, discussion board responses, virtual office, chat rooms, and threaded discussions should be used to meet the Millennials' need for close communication and contact with their lecturers. Further studies should investigate the Millennials' expectations regarding the appropriateness of different modes of communication in relation to the purpose of communication and instantaneity of feedback.

As the present study was conducted on Millennials who were still in the university and have not held full-time employment, their expectations of various aspects of their working life may not be realistic. Therefore, further studies should investigate the experiences of Millennials who have entered the Malaysian workforce. Findings of such studies can be used by universities to prepare Millennials for a transition from university life to working life, and reduce turnover due to maladjustments and help Millennials to achieve optimal productivity in a shorter time.

As the study was conducted on Millennials who were university students, the findings have direct implications on the generational clash between Millennial students, Generation X and Baby Boomer lecturers. Lecturers in these generational cohorts are not comfortable with the dependency of the Millennials in seeking repeated feedback on their work in progress. They feel that the Millennials do not know how to assess their own work in relation to set benchmarks, particularly since the marking criteria for coursework assignments are already made known to them. Millennials, on the other hand, need constant and immediate affirmation that they are getting it right before they move on to the next step because a trial-and-error process would culminate in them spending more time than planned on the assignments - which translates to less time on their personal life. Millennials also equate absence of feedback to lack of care (Pardue \& Morgan, 2008). To resolve the generational clash in expectations, peer evaluation can be taught to wean the students off their dependency on lecturers for feedback. Lecturers can use scaffolding to teach the millennial students to evaluate their peers' work using the marking criteria. In this way, they learn to assess the quality of their own work and to identify areas where they have fallen short of expected standards. Self-evaluation skill is vital for self-improvement, and it should be in the interest of Millennials to strive for the best. Meister and Willyerd stated that Millennials set very a high standard of personal and career goals to achieve, and the same benchmark should be applicable to study goals. Whether or not teaching the Millennials peer evaluation skills lead to better study outcomes, as envisaged, need to be investigated in further studies.

\section{Acknowledgement}

The authors would like to thank Diana Phooi-Yan Lee of Kuching Polytechnic, Sarawak, Malaysia for her assistance with the statistical analysis. 


\section{References}

"Modul pembangunan kemahiran insaniah untuk IPT Malaysia" [Module for development of soft skills for institutions of higher learning in Malaysia]. Retrieved from http://ftmk.utem.edu.my/obe/material/Kemahiran_insaniah.pdf

Asian Institute of Finance. (2015). Finance matters: Understanding GenY. Retrieved from http://www.aif.org.my/clients/aif_d01/assets/multimediaMS/publication/Finance_Matter s_Understanding_Gen_Y_Bridging_the_Knowledge_Gap_of_Malaysias_Millennials.pd $\mathrm{f}$

Black, A. (2010). Gen Y: Who they are and how they learn. Educational Horizons, 88(2), 92-101.

Koeller, M. (2012). From baby boomers to generation Y millennials: Ideas on how professors might structure classes for this media conscious generation. Journal of Higher Education Theory and Practice, 12(1), 77-82.

Lindquist, T. (2008). Recruiting the millennium generation: The new CPA. CPA Journal, $78(8), 56-59$.

Meister, C. J., \& Willyerd, K. (2010, May). Spotlight on leadership: The next generation mentoring millennials. Harvard Business Review. Pp 1-4.

Myers, K., \& Sadaghiani, K. (2010). Millennials in the workplace: A communication perspective on Millennials' organizational relationships and performance. Journal of Business \& Psychology, 25, 225-238. http://dx.doi.org/10.1007/s10869-010-9172-7

Ng, E. S., Schweitzer, L., \& Lyons, S. T. (2010). New generation, great expectations: A field study of the millennial generation. Journal of Business and Psychology, 25(2), 281-292. http://dx.doi.org/10.1007/s10869-010-9159-4

Ooi, K. B., \& Ting, S. H. (2014, August 28-30). Do employers highlight technical skills or soft skills in job advertisements? Paper presented at $12^{\text {th }}$ International AsiaTEFL Conference, Kuching, Malaysia.

Ooi, K. B., \& Ting, S. H. (2015a, Sept 14-15). Generation Y's expectations of working life. Proceedings of International Conference on Technical Vocational Education and Training 2015 (ICTVET2015), Pulau Pinang, Malaysia.

Ooi, K. B., \& Ting, S. H. (2015b). Work experience and polytechnic students' expectations of working life. Advanced Journal of Technical and vocational Education, 1(2), 1-8.

Pardue, K. T., \& Morgan, P. (2008). Millennials considered: A new generation, new approaches, and implications for nursing education. Nursing Education Perspectives, 29(2), 74-79. http://dx.doi.org/10.1043/1094-2831(2008)29[74:MCANGN]2.0.CO;2

Pricewaterhouse Coopers. (2009). Malaysia's GenY unplugged. https://www.pwc.com/my/en/assets/publications/gen-y.pdf 
Rainer, T. S., \& Rainer, J. W. (2011). The millennials: Connecting to America's largest generation. Nashville, Tennessee: LifeWay Research.

Reilly, P. (2012). Understanding and teaching Generation Y. English Teaching Forum, 50(1), $2-11$.

Stein, J. (2013, May 20). The new greatest generation: Millennials will save us all. Time, 28-35.

Thielfoldt, D., \& Scheef, D. (2004). Generation X and the Millennials: What you need to know about mentoring the new generations. Law practice today, ABS Law practice management. http://www. abanet. org/lpm/lpt/articles/mgt08044. html.

Ting, S. H. (2013). Researching to customize teaching for millennials. Insight: Unimas Teaching \& Learning Bulletin, 20, 4-5.

Twenge, J. M., \& Campbell, S. M. (2012). Who are the millennials? Empirical evidence for generational differences in work attitudes, values and personality. In $\mathrm{Ng}$, E., Lyons, $\mathrm{S}$. T., \& Schweitzer, L. (Eds.), Managing the new workforce: International perspectives on the millennial generation (pp. 1-19). Cheltenham: Edward Elgar Publishing. http://dx.doi.org/10.4337/9780857933010.00006

Wilson, M., \& Gerber, L. E. (2008). How generational theory can improve teaching: Strategies for working with the "millennials". Currents in Teaching and Learning, 1(1), $29-44$.

Woods, T., Wilson, T., \& Walkovich, D. (2011). Targeting instructional strategies to address Gen Y learner characteristics. The Journal of Physician Assistant Education, 22(2), 3841. http://dx.doi.org/10.1097/01367895-201122020-00008

\section{Copyright Disclaimer}

Copyright for this article is retained by the author(s), with first publication rights granted to the journal.

This is an open-access article distributed under the terms and conditions of the Creative Commons Attribution license (http://creativecommons.org/licenses/by/3.0/). 